\title{
Paleocurrent analysis as tool for reservoir property estimation: a case study of Eocene outcrops in Southeastern Nigeria

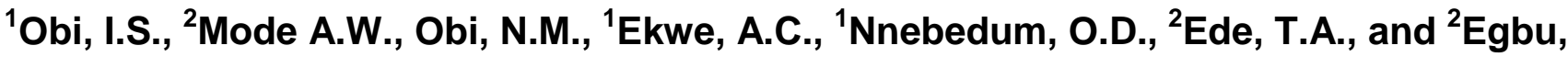 \\ O.C
} \\ ${ }^{1}$ Shell Chair of Geology, University of Nigeria, Nsukka \\ ${ }^{2}$ Department of Geology, University of Nigeria, Nsukka \\ E-mail: ifecoera@yahoo.com, wilfred.mode@unn.edu.ng
}

\begin{abstract}
Surface reservoirs belonging to the Ameki group were studied to evaluate the relationship between their reservoir properties and paleocurrent data. The permeability and effective porosities for selected reservoir sands was empirically determined using sieve data, while the paleocurrent properties namely vector strength and current variance was generated for crossbedded reservoir sands. Mathematical models which correlate the sedimentological, petrophysical and statistical properties of selected reservoir intervals were generated. The results show that the reservoir permeability values have near-excellent correlation with the effective porosities and median grain diameter for each sample, and very poor correlation with sediment sorting. It was also noted that higher permeability/effective porosities and lower permeability coefficients of variation (CVperm) were obtained in areas with higher current variance and lower vector strength. The reverse was the case where the current variance was low and vector strength was high. We also studied the behaviors of the permeability coefficient of variation and observed that better accuracy of effective porosity and permeability values was obtained in areas with low current variance and high vector strength, while a lower degree of accuracy was obtained in areas in with high current variance and lower vector strength. This study shows that it is possible to generate reservoir parameters from the grain size data, predict the reservoir depositional environments, and also predict where high or low accuracy occurs in petrophysical estimations.
\end{abstract}

Keywords: Paleocurrent, Permeability, Effective Porosity, Correlation coefficient

\section{INTRODUCTION}

About $50 \%$ of the world's petroleum reserve is estimated to occur in sandstones (Berg, 1986). The evaluation of reservoir architecture is a major challenge in development planning and reservoir management. Paleocurrent analysis has been found to be a useful tool to address the issues with improved reservoir descriptions. For example, channel orientations mapped from paleocurrent data are immensely helpful in understanding fluid movements (Shaikh et al., 2004; Teoh, 2007). Secondly, the delineation of major channels, identification of areas of bypassed oil and orientation of horizontal wells are being pursued by several authors on the basis of the study. Channel orientations are the key inputs used for reservoir descriptions in building of static and dynamic geologic models. Of late, the limitations of conventional reservoir description for evaluation of complex fluid movements in clastic reservoirs have been noted to account for most bypassed oil in the Burgan fields, North Korea (Shaikh et al., 2004).
Some authors have also carried out integrated studies involving paleocurrent analysis with core description, log signature analysis, reservoir pressure and production behaviours in order to delineate features dominantly controlling reservoir heterogeneity. Since current variance and vector strength have direct implications on the percentage accuracy of predicted reservoir parameters, it is advisable to carry out detailed evaluations of the relationships between the paleocurrent data and the reservoir sedimentology and petrophysics.

Petrophysical properties of reservoir rocks which include porosity, permeability, etc., are influenced by current velocity, degree of current variance, grain size, sorting, etc. These properties are partly controlled by facies characteristics which in turn are related to depositional environment. Outcrop models not only increase the knowledge of reservoir heterogeneity but also provide the foundation for which the rest of the subsurface reservoir and, simulation models can be built (Reynolds et al., 1998; Schatzinger and Tomutsa, 1999; Grammer et al., 
2004). In general, Paleocurrent studies enable the geologist to (i) predict the direction of elongation of a sandstone body, (ii) arrange its sedimentary fill, (iii) determine whether a structural feature in a basin was active during or after deposition, (iv) locate source regions that lie beyond a basin margin, ( $v$ ) aid paleoecology in establishment of supply direction of nutrient carrying current, (vi) contribute to resolution of some types of stratigraphic correlation problems, and (vii) grain fabric on bulk geophysical properties e.g. electrical and thermal conductivity. This study is aimed at evaluating the sedimentology and petrophysical properties of reservoir sandstones and paleocurrent data from Eocene siliciclastic sediments belonging to the Ameki Formation.

\section{GEOLOGICAL SETTING}

The Anambra Basin developed as a result of the Santonian event which greatly affected the Benue Trough terminating sedimentation in the Abakaliki Basin. Before then, sedimentation in southern Nigeria which began in the Early Cretaceous was facilitated by the break-up of the African and South American continents leading to the formation of the Benue Trough (Burke et al., 1970; Benkhelil, 1989). Sedimentation in the trough was controlled by 3 major tectonic phases, giving rise to 3 successive depocentres (Murat, 1972; Oboh-lkuenobe et al, 2005). The first phase (Albian - Santonian) featured the deposition of the Asu River Group, Ezeaku and Awgu formations within the Abakaliki-Benue Trough which was flanked to the west by the Anambra platform, and to the southwest by the Ikpe platform. The second phase (Campanian-Eocene) was characterized by compressive movements along the NE-SW axis which resulted in the folding and uplift of the Trough into an anticlinorium. This forced the Anambra platform to subside and the depocentre to shift south-westwards to the newly formed Anambra basin and the Afikpo syncline on the other side of the anticlinorium in the southeast. The deposition of the Nkporo Group, Mamu Formation, Ajali Sandstone, Nsukka Formation, Imo Formation and the Ameki Group then followed. Towards the end of Eocene, the third phase commenced and was characterized by the structural inversion of the Abakaliki region further shifting the depocentre down dip (Southwards) to form the Niger delta basin(Obi et al., 2001).

The Ameki group, interpreted to be deposited in foreshore - shoreface environments (Reijers et al., 1997) and delta front sedimentation (Anyanwu and Arua, 1990) based on lithological and trace fossil evidence, is underlain by the Paleocene Imo shale which comprises highly fossiliferous blue-gray clays and black shales with thin bands of calcareous sandstone, marl and limestone (Reyment, 1965). Oboh et. al. (2005) identified two depositional sequences in the Imo shale with each sequence bearing a striking similarity to estuarine cycles. The Imo Formation is the outcrop lithofacies equivalent of the Akata Formation in the subsurface Niger Delta (Short and Stauble, 1967; Avbovbo, 1978). Nwajide (1979) described the Nsugbe sandstone as comprising indurated, coarse and pebbly, unfossiliferous, ferruginized sandstones, probably of continental origin. The Naenka sands have been described by Simpson (1955) and Tattan (1944) as being loosely consolidated and coarse grained. Both Reyment (1965) and Adegoke (1969) described the formation as being heterogeneous, showing rapid facies changes based on the recognition of partly marine and non - marine to estuarine environment using fossil evidence. Nwajide's (1979) sedimentary model for the Nanka sands depicted deposition in a tidally influenced marine shoreline environment with a delineable intertidal zone. The Ameki Formation consists of alternating shales, sandy shale, clayey sandstone and fine grained fossiliferous sandstone with thin bands of limestone. Early Eocene and early middle Eocene ages have both been considered for the Formation by Reyment (1965) and Berggren (1960) respectively. Different depositional environments have been interpreted for the formation including a periodically swamped lagoonal environment by the Eocene sea, an estuarine environment based on presence of fish species of known estuarine affinity, and an open marine environment. A nearshore to intertidal and sub-tidal zones of the shelf environment was considered by Nwajide (1979) and Arua (1986) while Fayose and Ola (1990) preferred a marine environment with depth ranging from $10-100$ meters. Overlying the Ameki Formation is the lignite bearing Ogwashi Asaba Formation which comprises alternating coarse grained sandstone, lignite seams and light colored clays of continental origin (Kogbe, 1976). Reyment (1965) suggested an Oligocene - Miocene age for the Formation while Jan du Chêne et al. (1978) interpreted a Middle Eocene age based on palynological evidence. The Ameki Group and the Ogwashi - Asaba Formation are correlative with the Agbada Formation in the Niger Delta Basin.

\section{MATERIALS AND METHODS}

A systematic study of the sedimentological (grain size and sorting) and reservoir petrophysical properties 
(porosity and permeability) of sandstones was carried out on the sands, while paleocurrent data (vector strength, current variance and rose patterns) were analyzed in order to evaluate the relationships between all three datasets. Paleocurrent data were measured from the foreset planes of cross-bedded sand facies in thirteen outcrops in the study area shown in figure $(a-d)$. The study recorded the dominance of planar cross bed in the form of lowangle, high-angle, and tabular foresets, while some minor occurrences of trough beds were noted. Since outcrop exposures were poor and accessibility was poor, the paleocurrent measurements were recorded from the best available three-dimensional surfaces (figure 2). Two-dimensional surfaces indicate apparent paleo-flow patterns rather than true ones. Planar cross-bed sets in two-dimensions appear to suggest flow parallel to the outcrop. Flat, twodimensional surfaces without any indication about the three-dimensional nature of the bed-sets can create significant data collection errors and false paleo-flow directions (Sheldon, 2001). However, planar crossbeds are frequently not reliable, and a large number of readings were taken in order to provide an accurate estimate flow direction in the absence of trough cross-beds (High and Picard, 1974).
Sequences followed during measurements during this exercise include (i) measurement of dip amounts and azimuths from cross-beds, (ii) calculation of the mean vector azimuths (MVA), variance and vector strength using Steinmetz (1962) method.

$M V A=\tan ^{-1}(\Sigma \operatorname{Sin} A / \Sigma \operatorname{Cos} A)$,

Variance $($ Var $),{ }^{2}=\Sigma\left(A_{1}-A\right)^{2} / n-1$

Vector Strenght $=\sqrt{ }\left(\left(\left(\sum \operatorname{Sin} A\right)^{2}+\left(\sum \operatorname{Cos} A\right)^{2}\right) / n\right)$

Where $n$ is the number of readings, Sin $A$ and $\operatorname{Cos} A$ are the sines and cosines of the individual readings, respectively, and $\Sigma \operatorname{Sin} A$ and $\Sigma \operatorname{Cos} A$ are the sums of the sines and cosines of the individual readings (Collinson and Thompson, 1989). $A_{1}$ represents the individual azimuth readings, while $A$ represent the value of the mean vector azimuth.

Frequency distribution table $\left(0-360^{\circ}\right)$ was constructed using a class interval of $30^{\circ}$. The individual azimuths were tallied and the frequency of each interval was recorded. After the grouping, the data was used to plot rose diagrams (figure 1a-b). The current rose diagram is essentially a histogram converted to a circular distribution, with the modal class indicating the direction in which the current had dominantly moved. These circular histograms display the total number of observations.

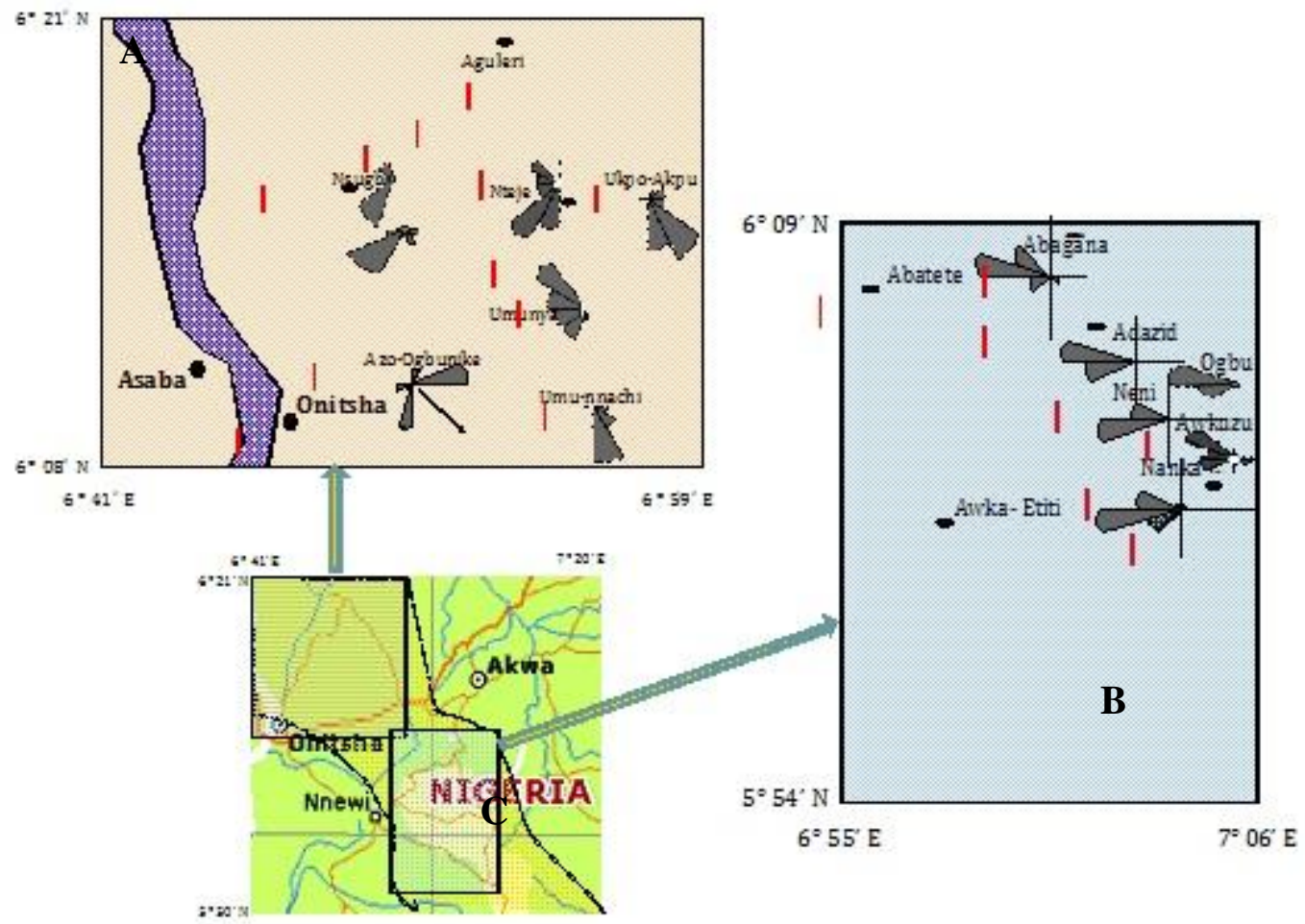

Fig 1(a-c). location map of study area (a \&b) with details of rose pattern distribution (Inset: map of Southern Nigeria, c). 
Am. J. Sci. Ind. Res., 2013, 4(1): 137-152

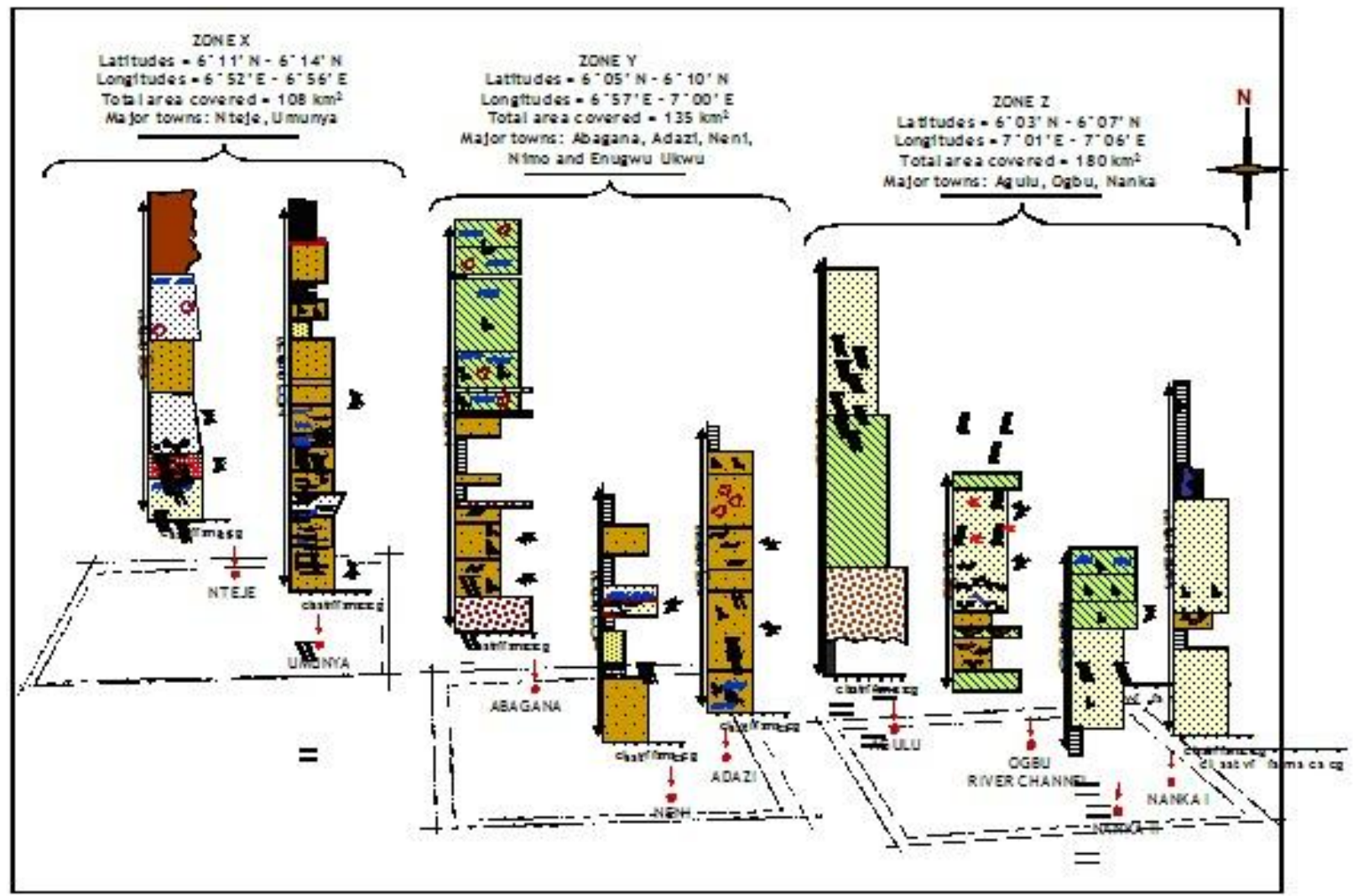

Fig 1d. Lithologs for the different outcrops studied.

paleocurrent data and reservoir sedimentology: Statistical analysis of paleocurrent data involves the estimation of mean vector and variance. Directional structures also provide information on current direction and are very important in this study. For a directional structure to be reliable, it must be easy to measure and widespread. It should also correlate with the direction of the principal current (Pettijohn, 1975; Obi, 2000). The vector strength and variance depend largely on the depositional process, flow regime and current pattern of the depositional medium. The vector strength is a measure of the magnitude and direction of the depositional medium that deposited the sediments. High values of vector strength indicate low dispersion while low values indicate high dispersion. The variance is a measure of the variability of the flow directions. Values of variance greater than 6000 indicate a shallow marine environment while values between 2000-6000 indicate fluvio-deltaic environments (Potter and Pettijohn, 1963). The mean vector azimuth (MVA) represents the average direction of the depositional agent. It is also applied in inferring regional slopes and the determination of sediment source of direction.

According to Teoh (2007), sedimentological studies have shown that porosity increases with increasing sorting (Fraser, 1935; Rogers and Head, 1961; Pryor, 1973; Beard and Weyl, 1973). Increasing sorting also correlates with increasing permeability (Krumbein and Monk, 1942; Beard and Weyl, 1973). A wellsorted reservoir sand contain grains that are about the same size and shape, while poorly sorted sands contain grains with different size and shape. The finer grains of the matrix block both the pores and throat passages within the framework for poorly sorted sediment but well-sorted sediment will have better porosity and permeability (Teoh, 2007). 
Am. J. Sci. Ind. Res., 2013, 4(1): 137-152
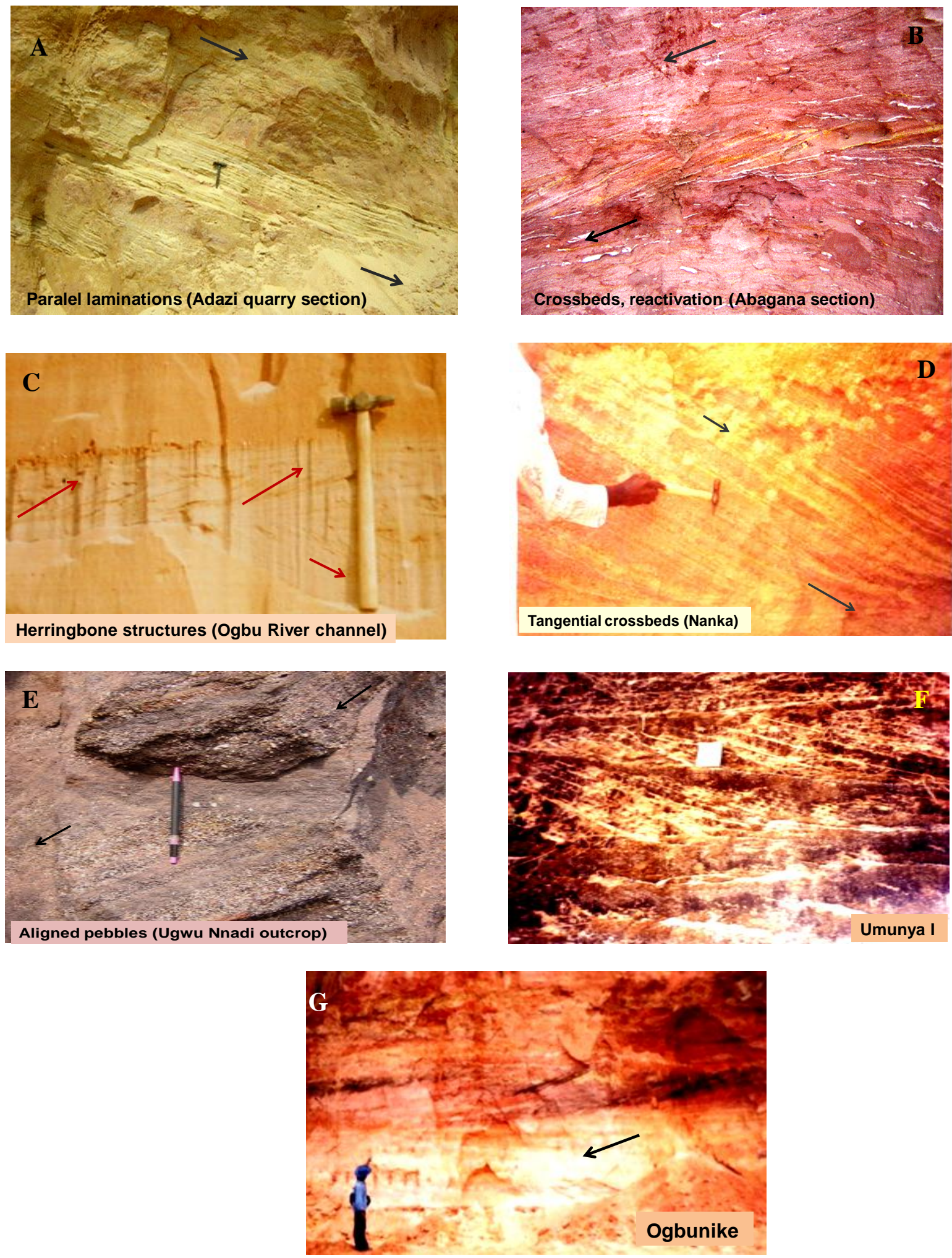

Fig 2(a-g). Sedimentary structures used in the paleocurrent analyses for different locations. 


\section{RESULTS AND DISCUSSION}

\section{A. Vector strength behaviour in reservoir sands}

The plot of vector strength against the average sorting generated a power curve. From the scatter diagram in figure $3 \mathrm{a}$, low vector strength values correspond to higher average sorting, while high vector strengths are obtained in poorly sorted sands. This means that with increased flow energy and turbulence, the sediments become more poorly sorted as the reservoir sands are deposited more abruptly. Where the particles are gently deposited, especially in low velocity current media, the reservoir sand particles are properly sorted into different coarse or fine packages. Although the scatter obtained for these reservoir sediments did not give a perfect correlation, the coefficient of correlation $\left(R^{2}\right)$ value of 0.7304 suggest that the current vector strength is inversely related to the sediment sorting (equation 1).

The plot of vector strength against the reservoir effective porosity (figure $3 b$ ) showed that they are inversely related, although with a low $R^{2}$ value (0.1191). The effective porosity in this study was computed using Tao and Roberts (2003) equations. The diagram (figure $3 \mathrm{~b}$ ) suggests that both parameters are poorly related. From the mathematical function generated (equation 2), we observe that increased current velocity deposits reservoir sands with lower effective porosity and vice versa. The vector strength versus reservoir permeability plot (figure 3c) is similar to the previous in figure $3 \mathrm{~b}$. Here it is noted again that the permeability of the reservoir sands decreases with increasing vector strength thereby suggesting that areas where sediments were deposited during higher energy conditions would have low permeability sands. In other words, more poorly sorted sediments with lower porosity and permeability are deposited during higher and more turbulent energy conditions. The scatter plot in figure also shows that the points are poorly correlated $\left(R^{2}=0.0195\right)$ (equation 3 ).

The coefficient of variation (CV) is used in probability theory and statistics as a normalized measure of dispersion of probability dispersion. It is defined as the ratio of the standard deviation $(\sigma)$ to the mean $(\mu)$. Essentially, the CV represents the degree of variance of the statistical parameter. Distributions with $C V<1$ are considered low variance, while those with $\mathrm{CV}>1$ (such as hyper-exponential distribution) are considered high variance. The data plot for current vector strength and the permeability coefficient of variation $\left(\mathrm{CV}_{\text {perm }}\right)$ show a polynomial relationship (figure $3 \mathrm{~d}$ ). The correlation coefficient value $(0.3758)$ is fairly low because the points do not fit perfectly along the line curve. From the third-orders polynomial function generated (equation 4) and the scatter diagram shown, it is difficult to predict the relationship between depositional energy and the reservoir permeability coefficient of variation $\left(\mathrm{CV}_{\text {perm }}\right)$.

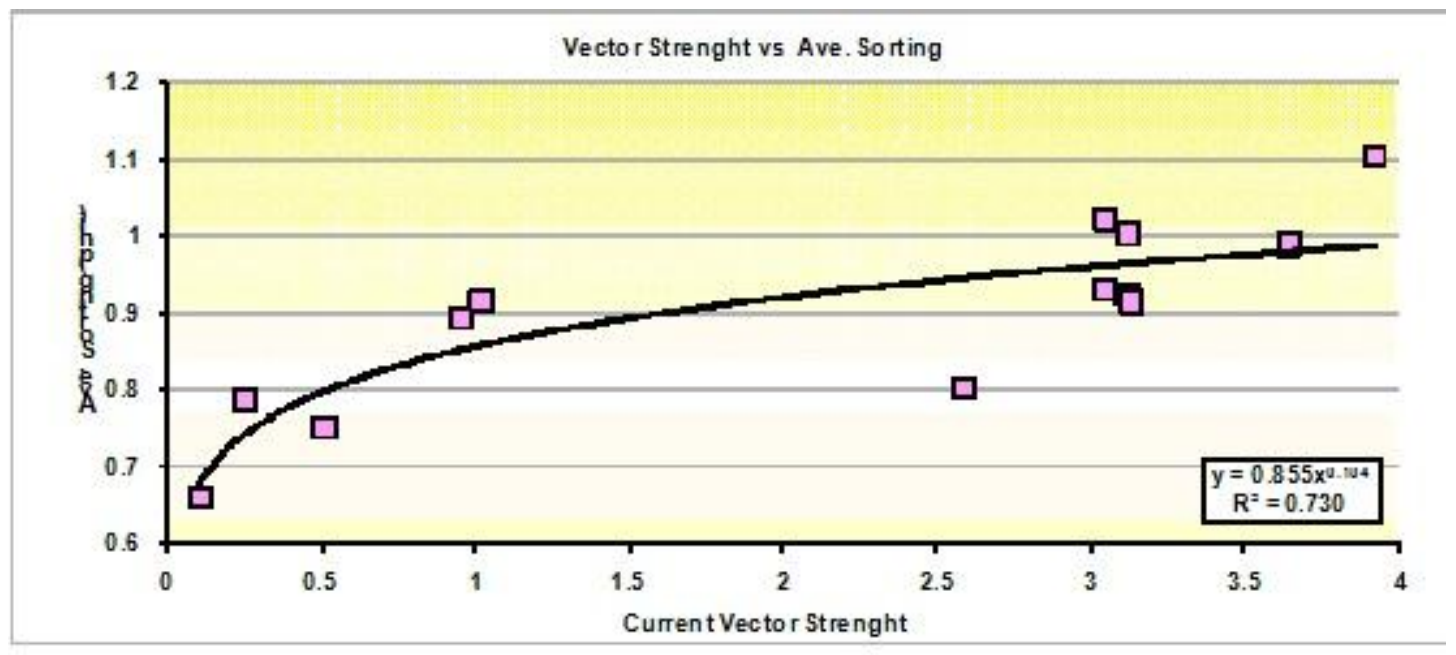

Fig 3a. Current vector strength versus average sorting (phi)

$y=0.855 x^{0.104}\left(R^{2}=0.730\right)$. Eqn. 1 
Am. J. Sci. Ind. Res., 2013, 4(1): 137-152

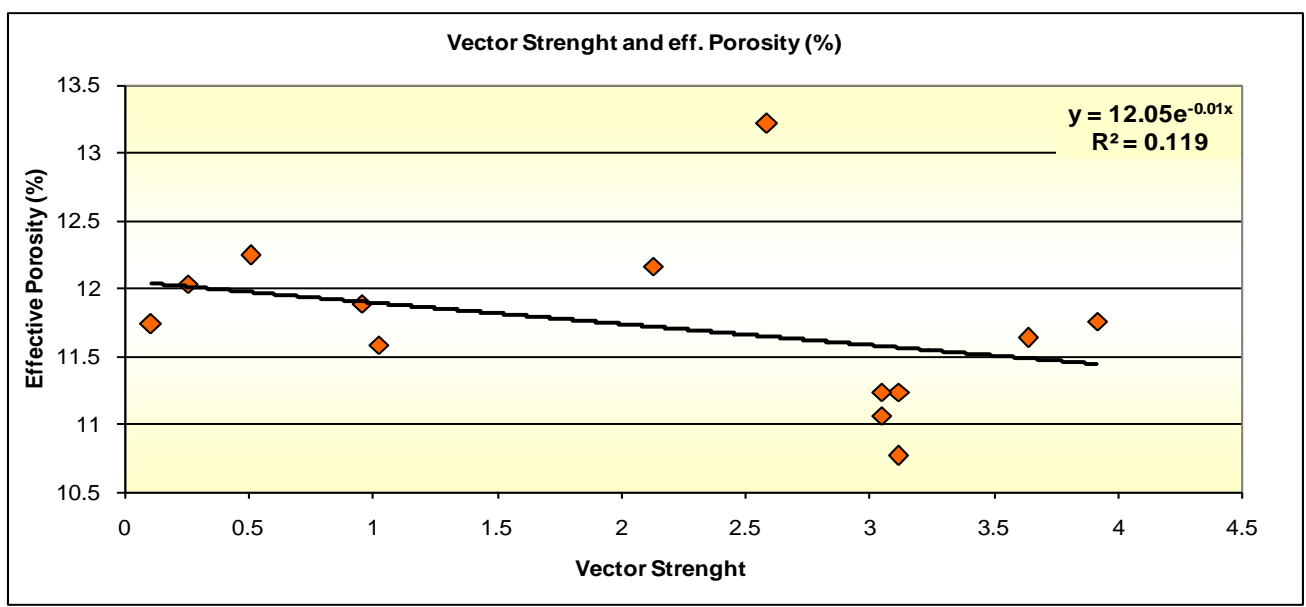

Fig 3b. Current vector strength versus effective porosity (\%)

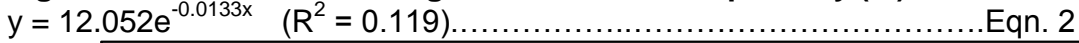

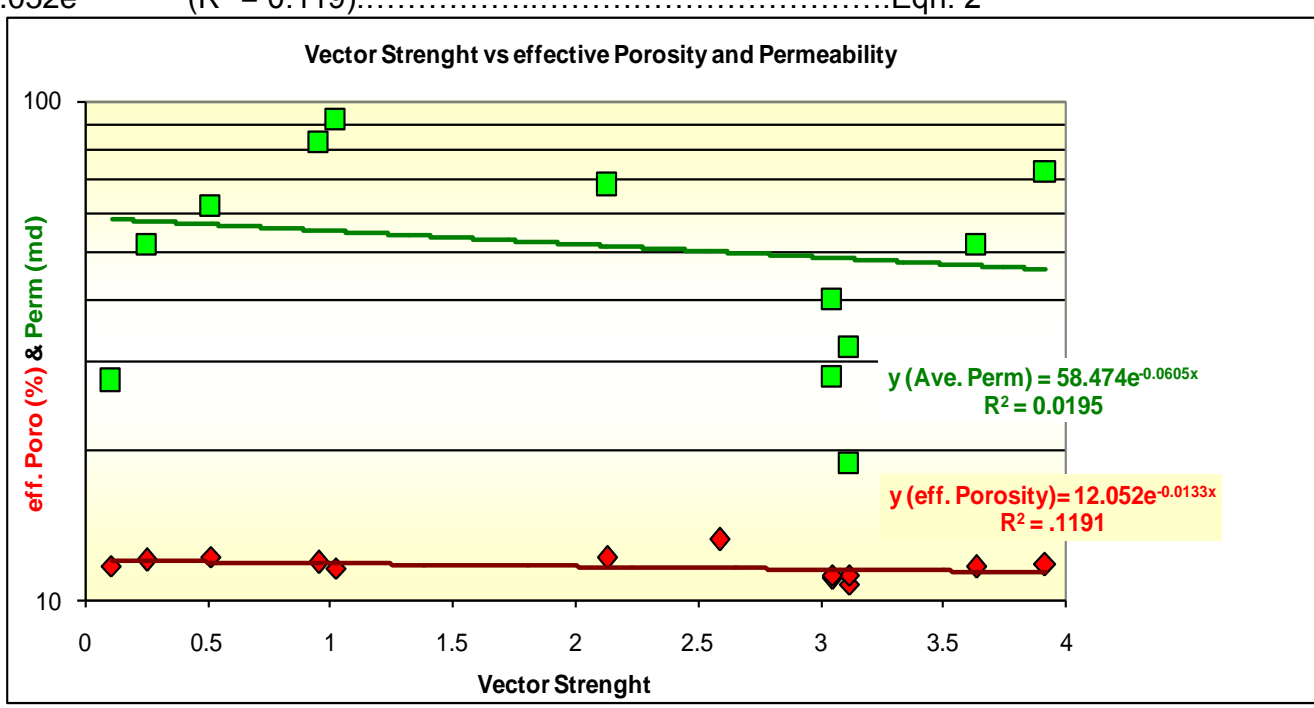

Fig 3c. Current vector strength versus effective porosity (\%) and permeability (md)

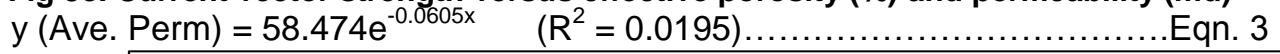

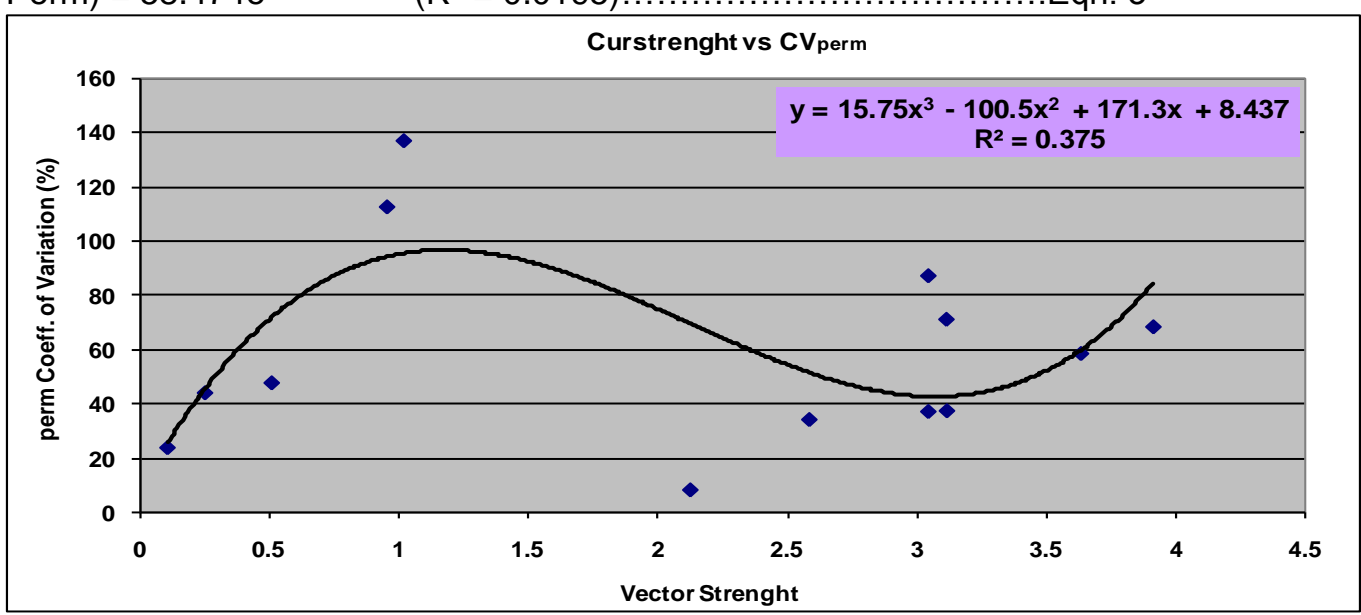

Fig 3d. Current vector strength versus permeability Coefficient of Variation(\%)

$y=15.752 \times 3-100.55 x^{2}+171.39 x+8.4375\left(R^{2}=0.3758\right)$.

Eqn. 4 


\section{B. Current variance behaviour in reservoirs}

Variance is a dimensionless quantity which depicts the degree of variability of the current medium, and ranges between $<1$ to $>6000$, depending on the depositional environment. The variance versus the reservoir effective porosity plot (figure 4a) shows that the current variance and the effective porosity have low correlation $\left(R^{2}=0.2634\right)$. The diagram also shows that the variance-porosity points are clustered near the curved end of the line, which probably suggest that at very low paleocurrent variance (say $\leq 500$ ), the effective porosity-variance trend is unclear. The current variance versus the average permeability plot (figure 4b) shows that the points are fairly dispersed around the line of fit especially at higher current variance ( $\geq 2000)$, and the trend obtained is similar to that in previous plots with effective porosity (figure 4a). The low $R^{2}$ value $(0.022)$ implies that the variance and permeability of these reservoir sands are poorly correlated.

The graph in figure 4c shows that current variance is inversely related to vector strength. This means that variations in paleocurrent direction are lower in environments with high depositional energy (e.g. in tidal or fluvio-deltaic settings). The $R^{2}$ value $(0.7632)$ indicates a positive correlation between the current variance and vector strength as shown by the logarithmic function given in equation 7 .

As earlier stated, the coefficient of variation for any statistical parameter in a distribution refers to the degree of variance with respect to its deviation from the mean value. The plots shown in figure $4 \mathrm{~d}$ depicts the behaviour of the current variance with different permeability coefficient of variation $\left(\mathrm{CV}_{\text {perm }}\right)$ values. The mathematic formula generated shows that the $\mathrm{CV}_{\text {perm }}$ is a logarithmic function of the magnitude of the paleocurrent variance (equation 8). The highest $R^{2}$ value obtained (0.4089) indicates a good positive correlation between these parameters. From the curved line of fit, it is deduced that both parameters are near inversely correlated. This means that depositional environmental with high current variance would record permeability values which are less dispersed from the mean (i.e. a higher level of confidence), and vice versa. This relationship implies that higher dispersion (from the mean) in permeability data is obtained if the reservoirs sands were deposited by low variance currents. Hence, a higher degree of uncertainty with respect to predicted permeability and effective porosity values.

The current variance versus sorting relationship is given by the logarithmic function (equation 9, $\left.\mathrm{R}^{2}=0.6737\right)$. Both parameters are positively correlated (figure 4e) implying that the current variance and sediment sorting are directly proportional to each other. This suggests that reservoir sands deposited under low energy conditions (highly dispersed current directions or high variance, e.g. in shallow marine settings) are better sorted than those deposited by high energy currents (low variance, e.g. tidal or alluvial settings). From same figure, it is also noticed that the relationship between variance and sorting becomes unclear at very low variance. Same trend was noticed in the previous section relating the effective porosity and average reservoir permeability at low current variance (say $\leq 5000$ ).

\section{(c) Permeability relationship with reservoir sedimentology}

The plot of permeability versus the effective porosities of samples (figure $5 \mathrm{a}$ ) show an excellent positive correlation $\left(R^{2}=0.8578\right)$, while the permeability versus sorting plot (figure $5 \mathrm{~b}$ ) produced a logarithmic function with a low $R^{2}$ value of 0.0812 (equation 11). The low correlation coefficient indicates that the permeability of these sediments is poorly correlated with its sorting. The trend of the line-of fit also show that better sorted reservoir sands have higher permeability values, and vice versa.

Permeability variation with median diameter of the reservoir sands is shown in figure $5 c-d$. Depending on the scale used for median size, the permeability and median diameter are near excellently correlated $\left(R^{2}=0.9001\right)$ by power and exponential functions (equations $12 \mathrm{a} \& 12 \mathrm{~b}$, respectively). The trend of the line in equation 12 a reveals that permeability is lower in sediments with lower median diameter, and both parameters vary exponentially.

(d) Derived versus Predicted Permeability Two sets of permeability values were generated for comparison after their plots were made on the same scale. The plot of both datasets, the first being derived permeability values (from Hsu 1977 equation), and the second being the predicted values using equation $12 \mathrm{~b}$, show a good positive correlation $\left(R^{2}=0.90\right)$ between both permeability data. We used equation $12 \mathrm{~b}$ to compute predicted values because it generated a higher $R^{2}$ value $(0.9001)$ compared to $R^{2}$ values from equation $10\left(R^{2}=0.8578\right)$ and equation $11\left(R^{2}=0.0812\right)$. This suggests that permeability values of reservoir sands in this area are better correlated to median size than effective porosity and sorting. Equation 13 shows that the reservoir permeability values generated from our equation had a very good correlation with the permeability values generated using Hsu's 1977 model (figure 6a-b). 
Am. J. Sci. Ind. Res., 2013, 4(1): 137-152

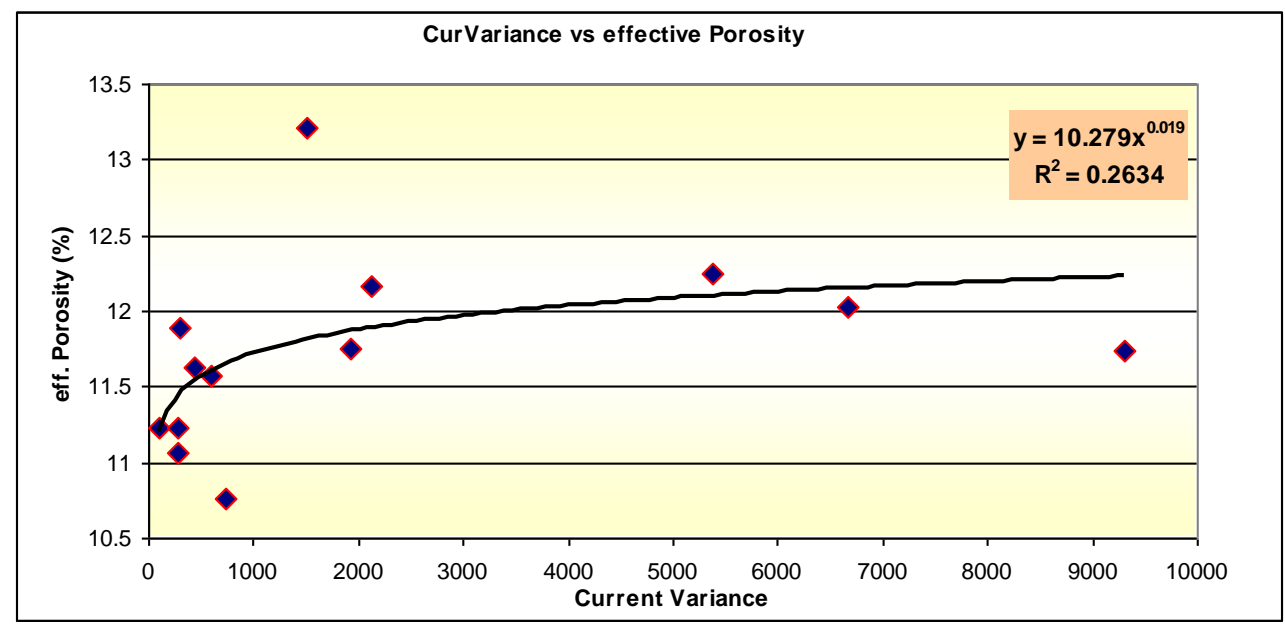

Fig 4a. Plot of current variance versus effective porosity (\%) of the reservoir sands $y=10.279 x^{0.019}\left(R^{2}=0.2634\right)$. ...qn. 5

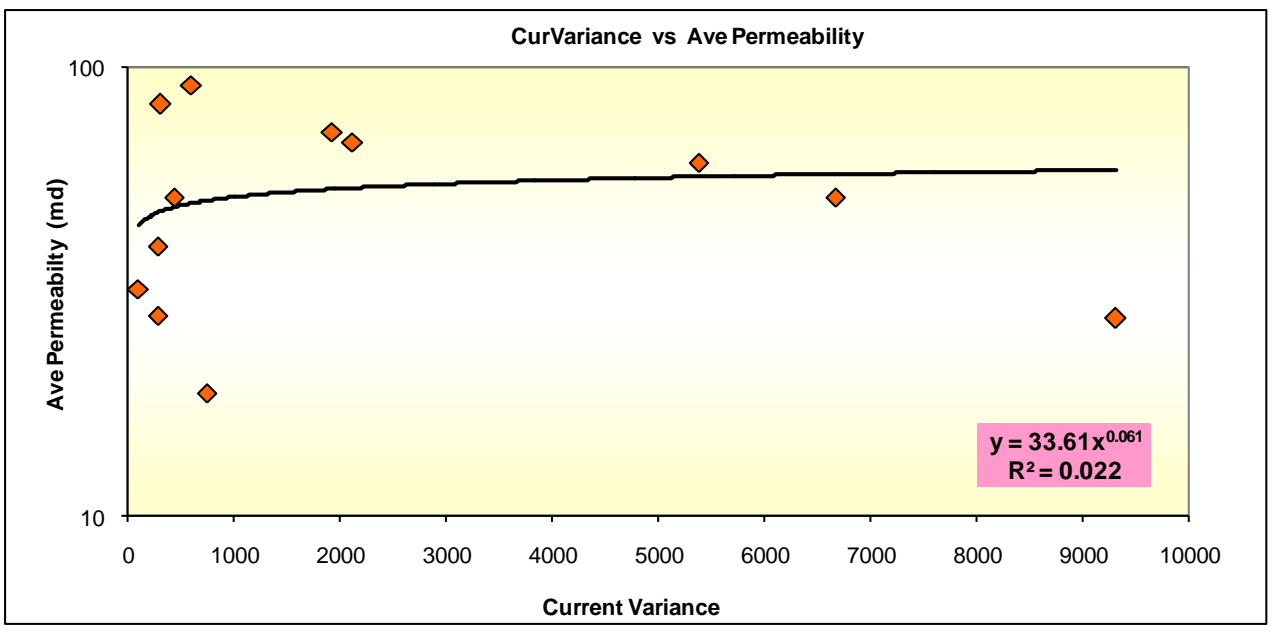

Fig $4 \mathrm{~b}$. Plot of current variance versus average permeability (md) of the reservoir sands

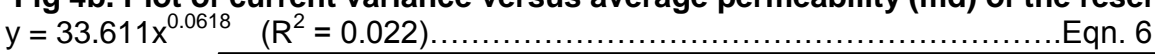

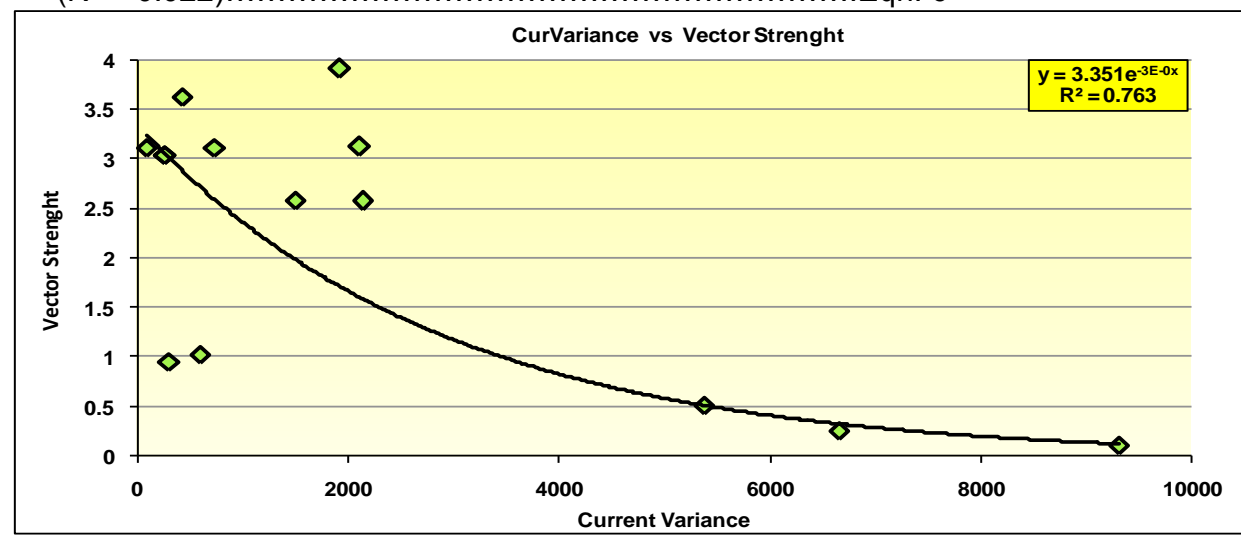

Fig 4c. Plot of current variance versus vector strength $y=3.351 e^{-3 E-0 x}\left(R^{2}=0.763\right)$. Eqn. 7 
Am. J. Sci. Ind. Res., 2013, 4(1): 137-152

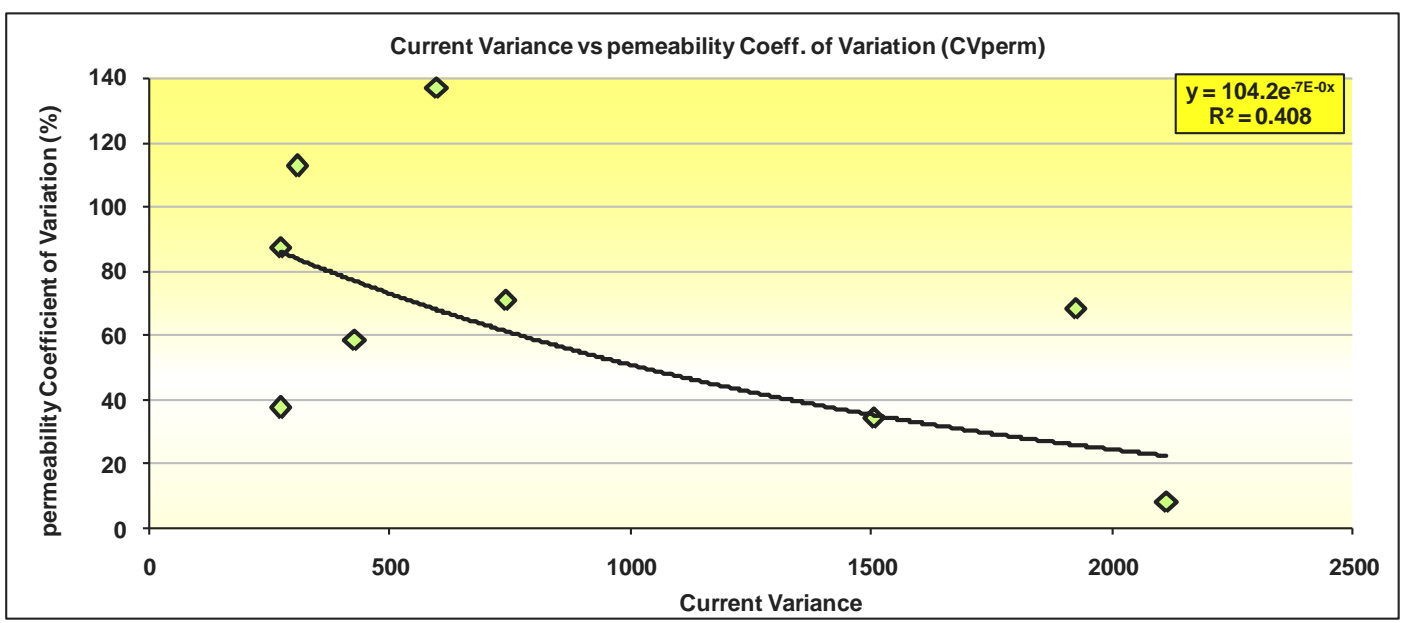

Fig 4d. Plot of current variance versus permeability coeff. of Variation (\%)

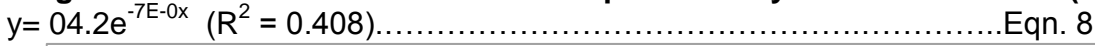

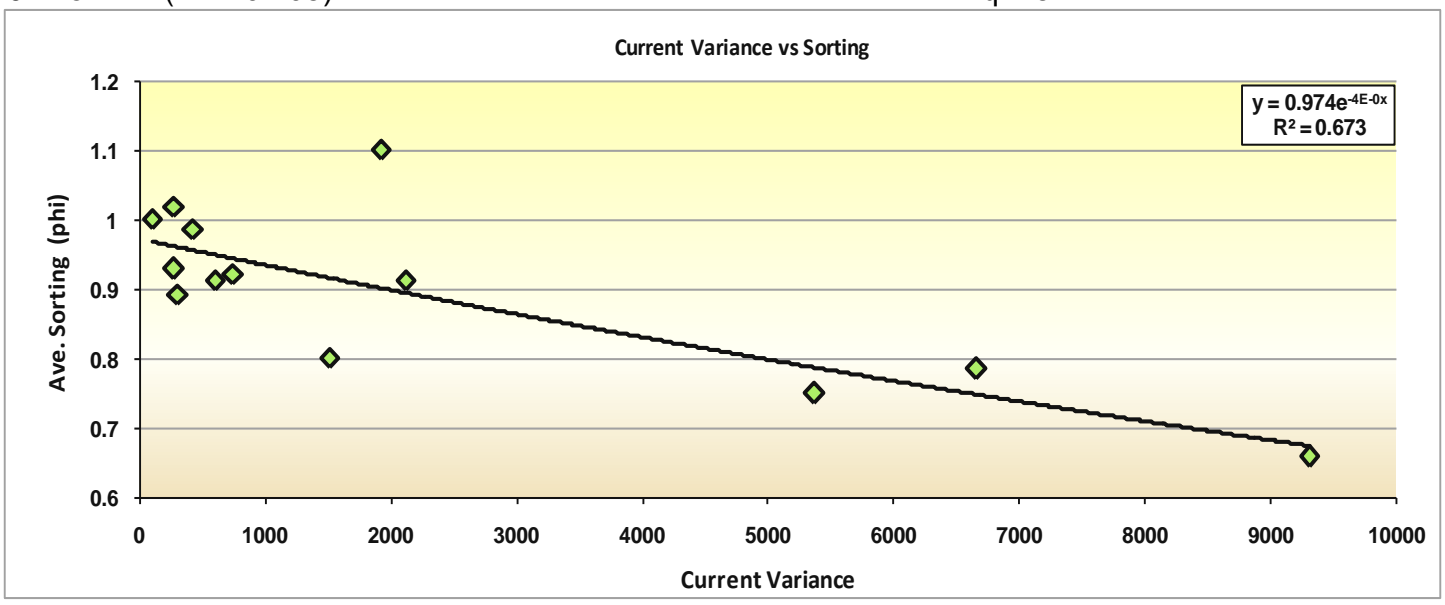

Fig 4e. Plot of current variance versus Average Sorting (phi) $y=0.974 e^{-4 E-0 x}\left(R^{2}=0.673\right)$.

Eqn. 9

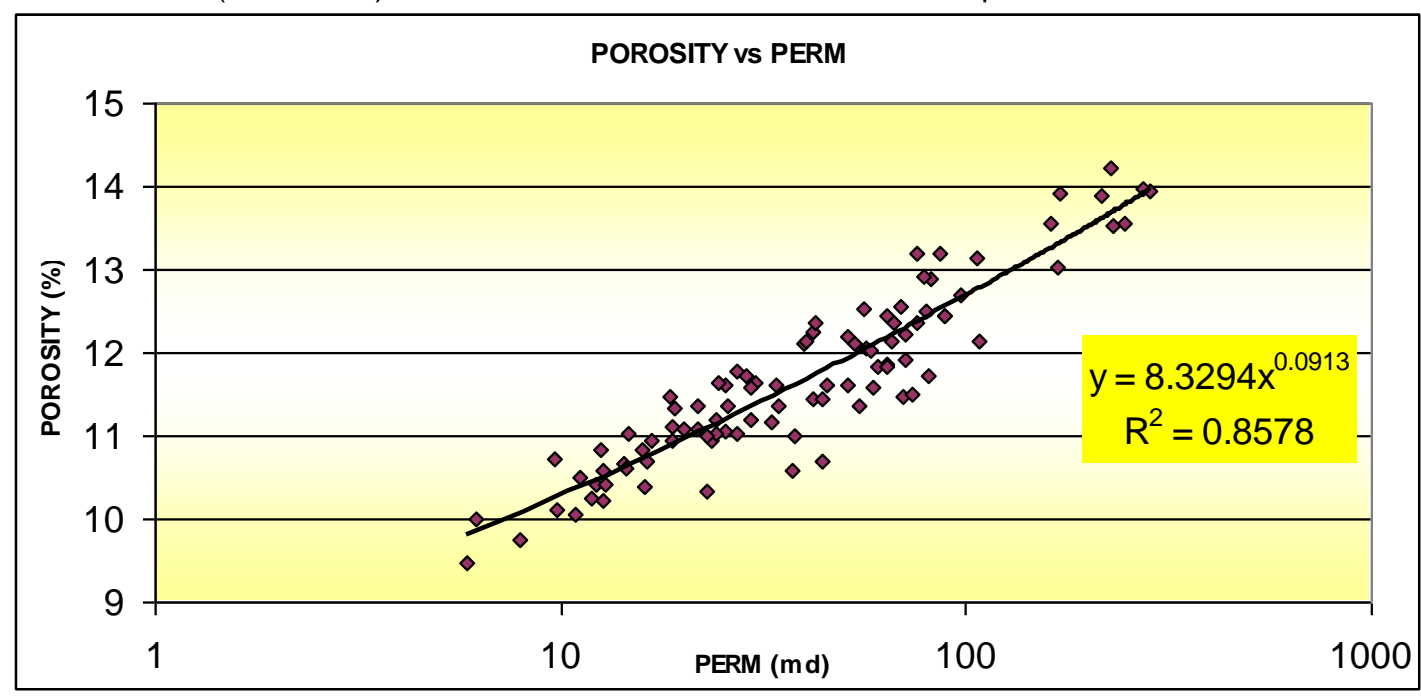

Fig 5a. Plot of permeability (md) versus effective porosity (\%) for selected samples $y=-8.3294 x^{0.0913} \quad\left(R^{2}=0.8578\right)$ Eqn. 10 
Am. J. Sci. Ind. Res., 2013, 4(1): 137-152

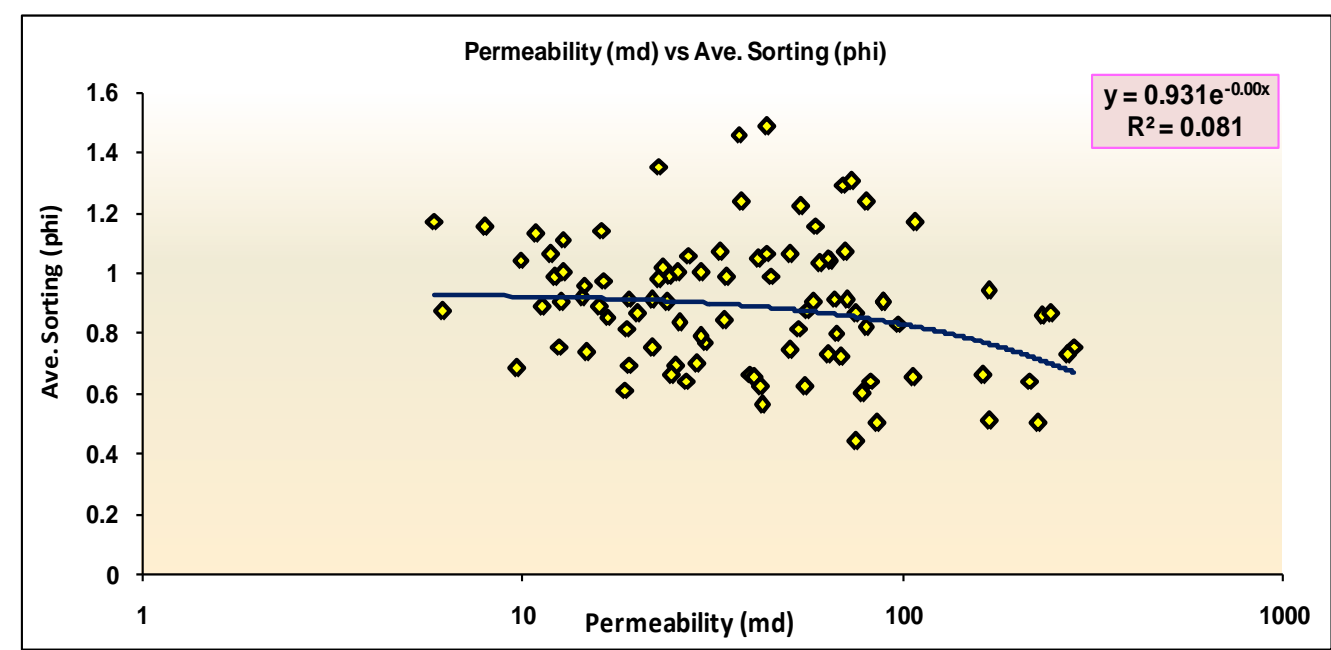

Fig 5b. Permeability ( $\mathrm{md}$ ) versus average sorting for selected samples

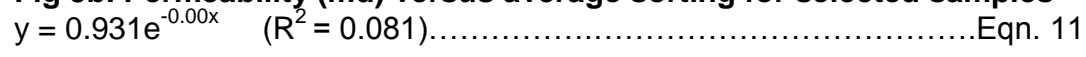

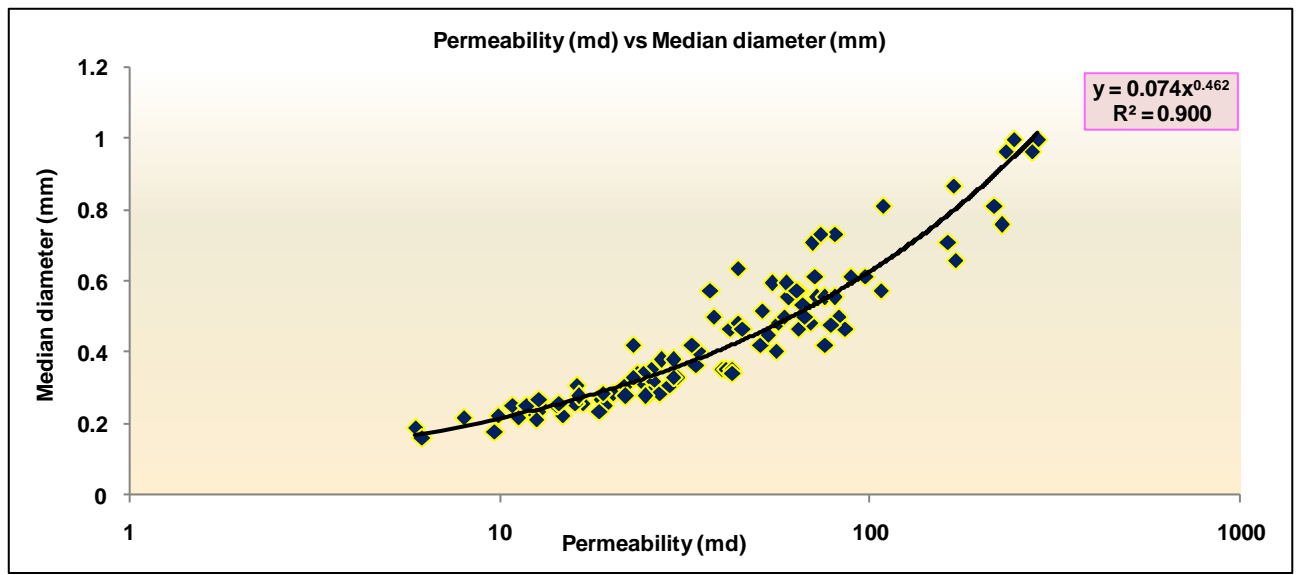

Fig 5c. Permeability (md) versus median diameter (mm)

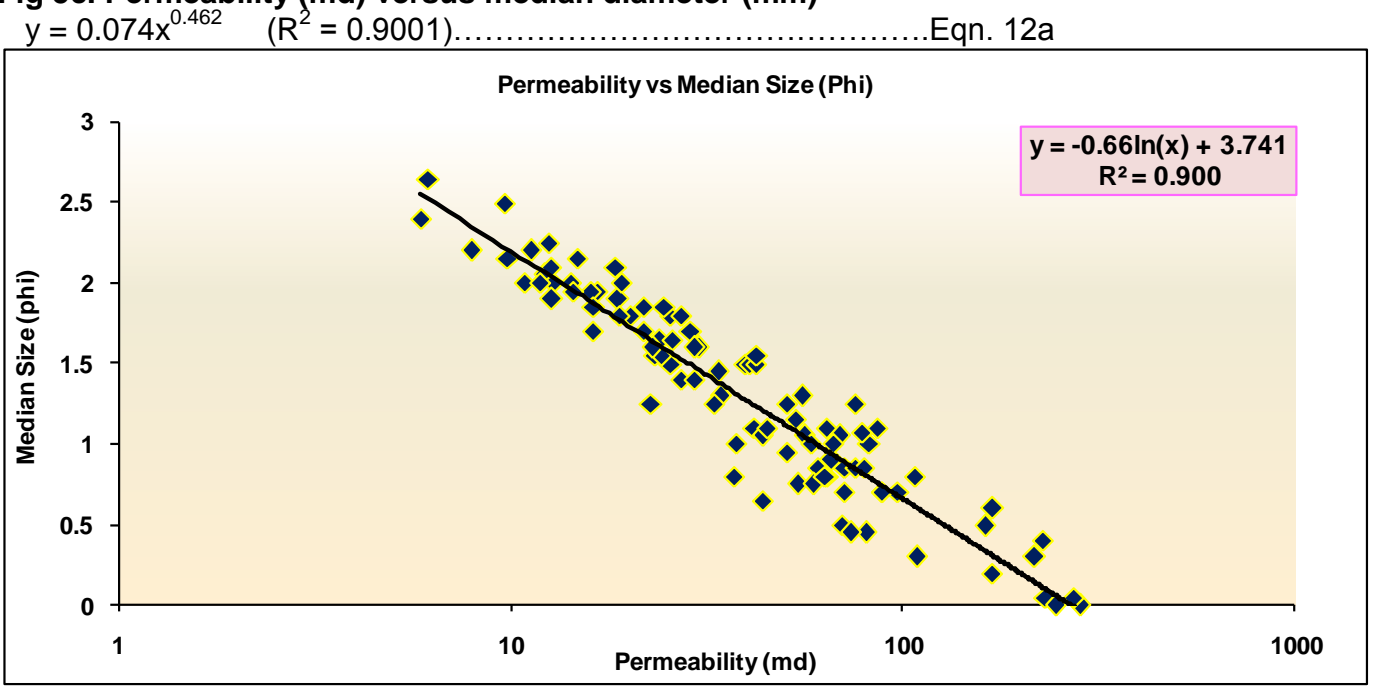

Fig 5d. Permeability (md) versus median size (phi)

$y=223.8 e^{-1.3485 x} \quad\left(R^{2}=0.9001\right) \ldots$

Eqn. $12 b$ 
Am. J. Sci. Ind. Res., 2013, 4(1): 137-152

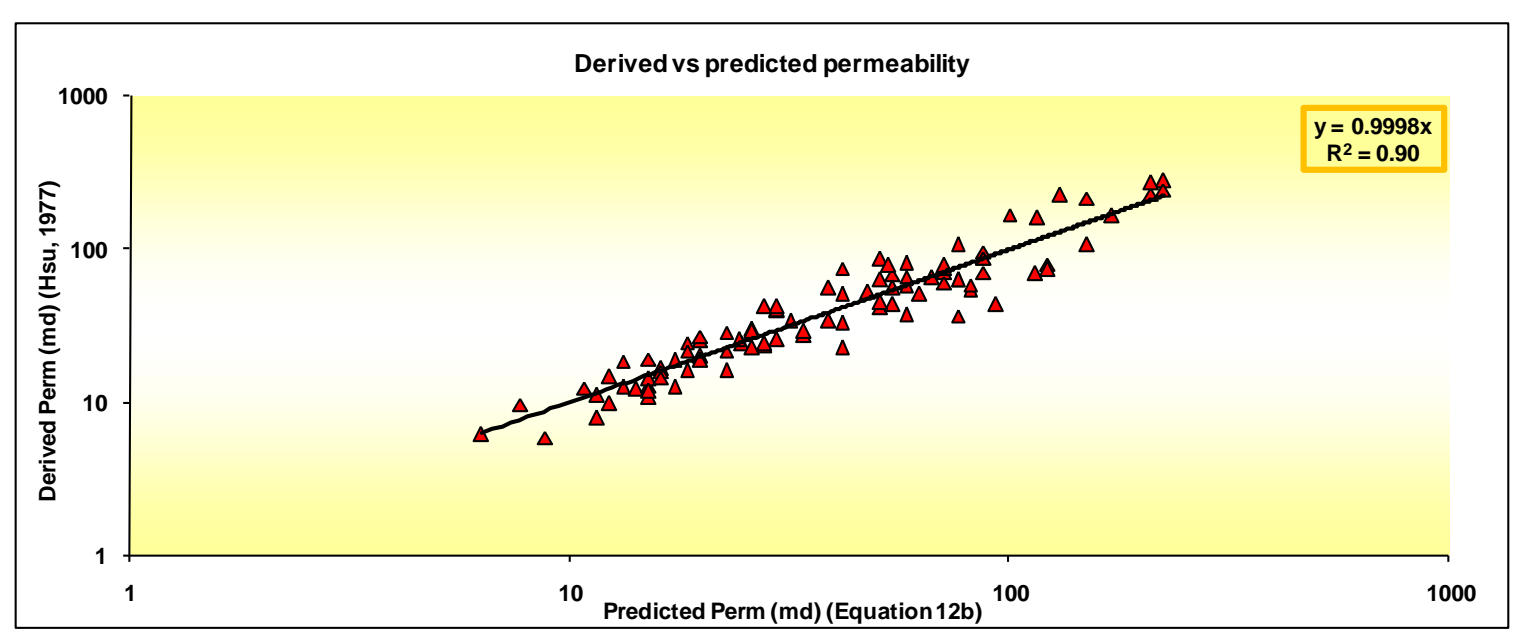

Fig 6a. Plot of derived permeability (Hsu, 1977 equation) versus predicted permeability (using equation 12a) $y=0.9998 x \quad\left(R^{2}=0.90\right)$ Eqn. 13

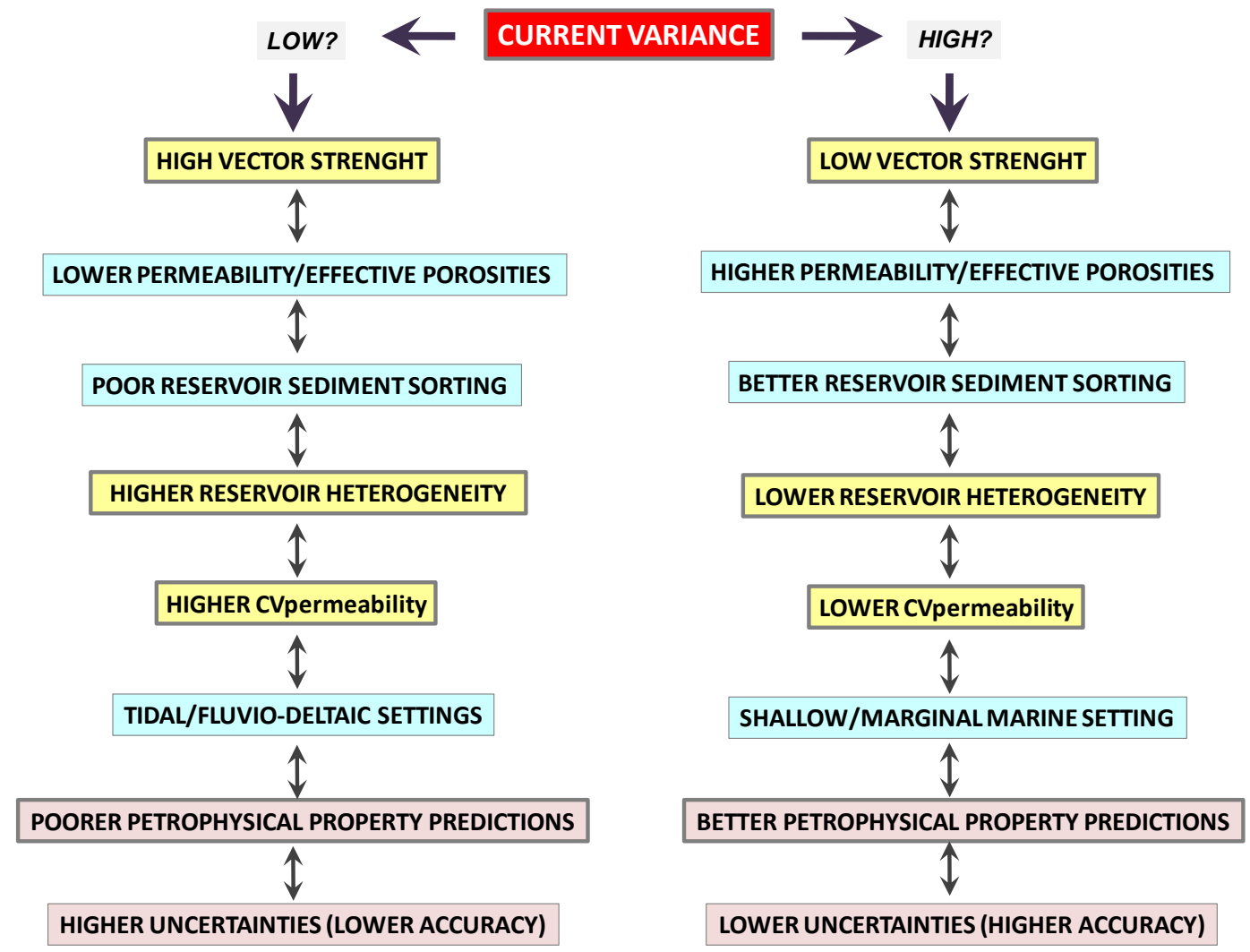

Fig 7. Flow chart for 'quick-look' reservoir evaluation given the paleocurrent data 
Am. J. Sci. Ind. Res., 2013, 4(1): 137-152

APPENDIX: APPENDIX (PALEOCURRENT AND RESERVOIR PROPERTY DISTRIBUTION IN STUDY LOCATIONS)
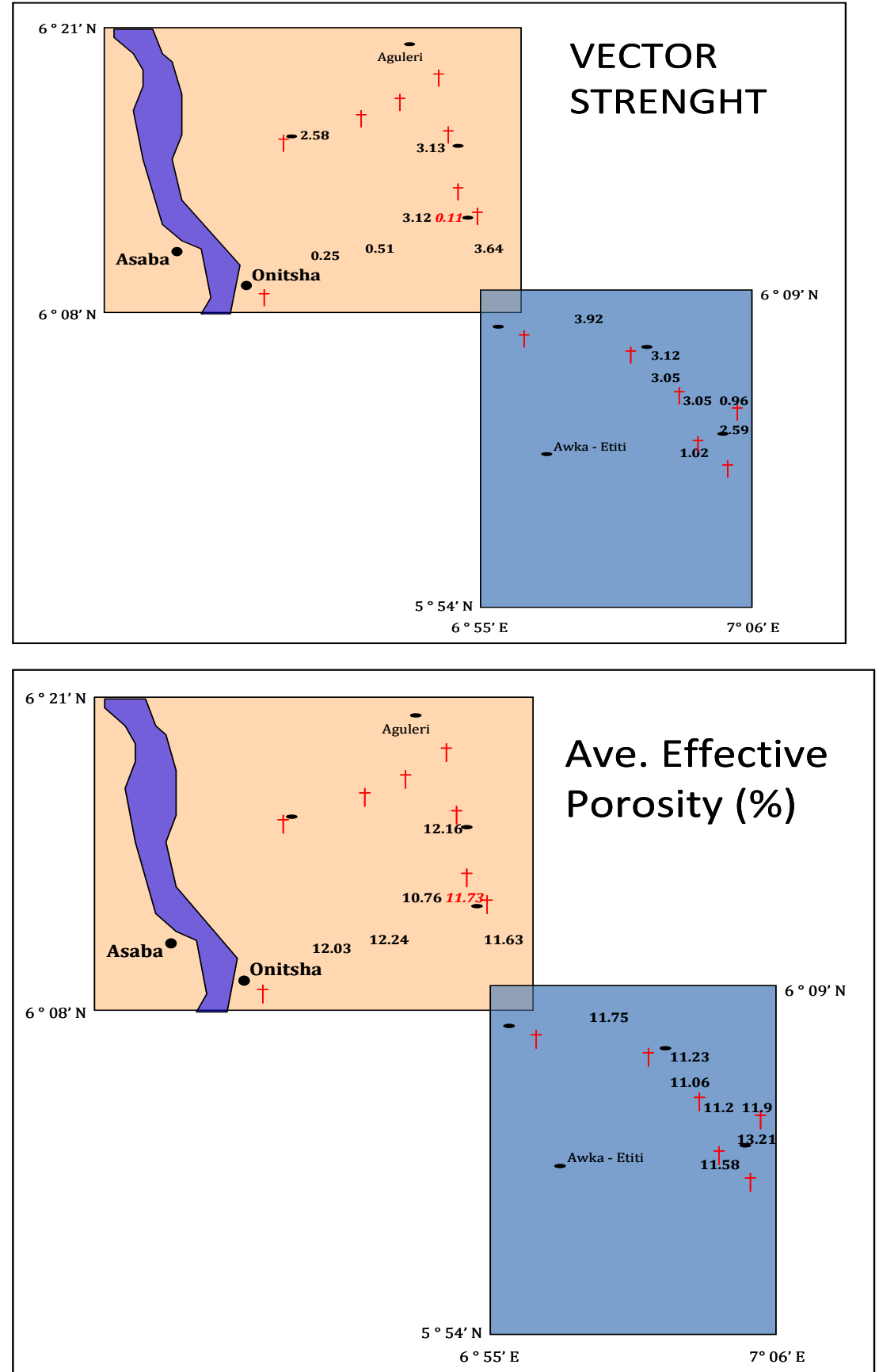
Am. J. Sci. Ind. Res., 2013, 4(1): 137-152
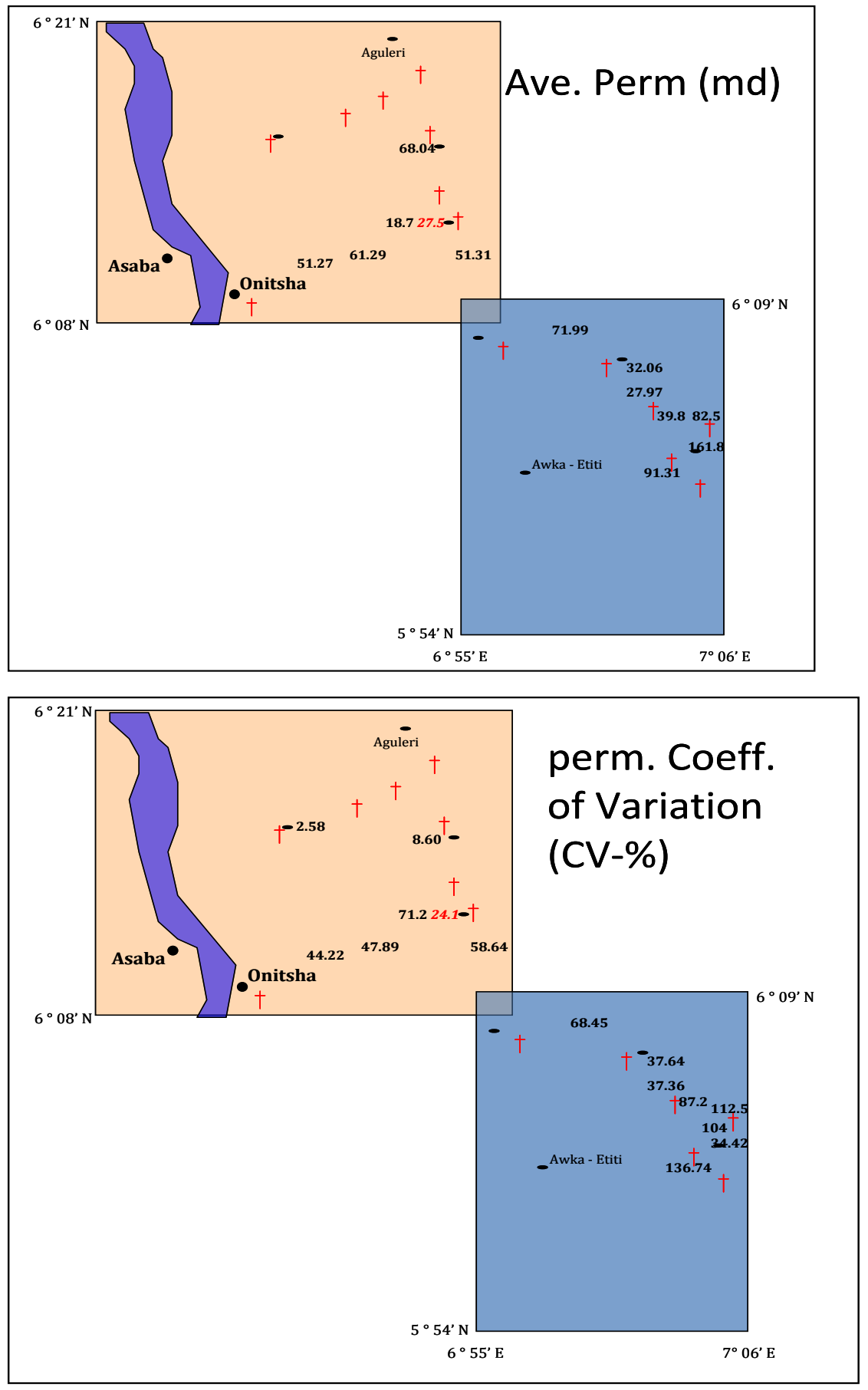


\section{CONCLUSION}

Our studies have shown that permeability values, especially for these reservoirs, have excellent correlation with the effective porosities and median grain diameter, and very poor correlation with the sediment sorting. This suggests that the median diameter of sand grains is more reliable for estimation and prediction of reservoir permeability. We also recorded higher permeability and effective porosities, and lower permeability coefficients of variation (CVperm) in areas with higher current variance and lower vector strength. This reveals that the depositional environment of reservoir sands is a major control on the reservoir quality and heterogeneity. The reverse is the case where the current variance is low and vector strength is high. It is our opinion that a better accuracy for effective porosity and permeability predictions (i.e. a lower uncertainty in estimations) is obtained if the reservoir sands were deposited by a low current variance and high vector strength. The reverse is true if the current variance was high and the vector strength was low.

Summarily, it is possible to predict the permeability/effective porosities, sediment sorting, reservoir heterogeneity, depositional environments, and the CVperm values, given the current variance and vector strength (figure 7).

\section{REFERENCES}

Adegoke, O.S., 1969. Eocene Stratigraphy of Southern Nigeria. Colloque sur I' Eocene, III. Bureau de Recherché Geologiques et Minieres, Vol. 69, p. $20-$ 48.

Anyanwu, N.P.C., and I. Arua, 1990. Ichnofossils from the Imo Formation and their Paleoenviromental significance, Journal of Mining and Geology, Vol. 26, p. 2-6.

Avbovbo, A. A., 1978. Tertiary lithostratigraphy of the Niger Delta, AAPG Bulletin, Vol. 62, p. 290-307.

Beard, D.C. and Weyl, P.K. 1973. "Influence of Texture on Porosity and Permeability of Unconsolidated Sand," AAPG Bull., Vol. 57, No. 2, (1973), 349-369.

Benkhelil, M., M. Guiraud, J.F. Ponsard, and L. Saugy, 1989. The Bornu-Benue Trough, the Niger Delta and its Offshore: Tectono-sedimentary Reconstruction during the Cretaceous and Tertiary from Geophysical data and Geology, In Kogbe, C.A. (ed.) 1989, Geology of Nigeria, Elizabethan Publ.Co. Lagos, p. 277-309.

Berg, R.R., 1986. Reservoir Sandstones: Prentice-Hall, Inc, Englewood Cliffs, New Jersey, 481p.

Burke, K.C., T.F.J. Dessauvagie, and A.J. Whiteman, 1970. Geological history of the Benue Valley and Adjacent areas, In T.F.J. Dessavaugie and A.J. Whiteman, eds.,
African Geology: University of Ibadan press, p.181186.

Collinson, J.D, and D.B. Thompson, (1989/82). Sedimentary Structures, Chapman and Hall, London, 207p.

Fayose, E.A. and P.S. Ola, 1990. Radiolarian occurrences in the Ameki Type Section, Eastern Nigeria, Journal of Mining and Geology, Vol. 26, p.70-79.

Grammer, G.M., P.M. Harris, and G.P. Eberli, 2004, Integration of Outcrop and Modern analogs in Reservoir Modelling: Overview with example from the Bahamas, In Integration of Outcrop and Modern analogs in reservoir Modelling: AAPG Memoir 80, p.1 -22 .

High, L.R., and M.D. Picard, 1974. Reliability of cross stratification types as paleocurrent indicators in fluvial rocks. Journal of Sedimentary Petrology, V.44 (1), pp.158-168, In Teoh 2007: Characteristics of sedimentary Facies and Reservoir Properties of some Tertiary sandstones in Sabah and Sarawak, East Malaysia. Unpublished MSc thesis, School of Physics, University of Sains, Malaysia. 119pp.

Hsu, K.J., 1977, Studies of Ventura Field, California, II. Lithology, Compaction, and Permeability of sands: AAPG Bull., v.61, p.169 - 191.

Jan du Chêne, R., Onyike, M.S. and Sowami, M.A. 1978. Some new Eocene pollen of the Ogwashi-Asaba Formation, southeastern Nigeria, Revista de Espand Micropaleontology, Vol. 10 (2), p. 285-320.

Krumbrien, W.C., and G.D. Monk, 1942, Permeability as a function of size parameters of unconsolidated sand: Pet. Technol, v.5, p.1-11.

Murat, R.C., 1972, Stratigraphy and Paleogeography of the Cretaceous and lower Tertiary in Southern Nigeria, In T.F.J. Dessauvagie and A.J. Whiteman, eds., African Geology: Univ. Ibadan Press, p.251 - 266.

Nwajide, C.S., 1979. A lithostratigraphic analysis of the Nanka Sands, south-eastern Nigeria, Journal of Mining and Geology, Vol. 16, p. 100-110.

Obi, G.C., C.O. Okogbue, and C.S. Nwajide, 2001. Evolution of the Enugu Cuesta: A tectonically driven erosional process, Global Journal of Pure Applied Sciences Vol. 7, p. 321-330.

Oboh-lkuenuobe, E.F, G.C. Obi, and A.C. Jamarillo, 2005. Lithofacies, Palynofacies and Sequence Stratigraphy of Paleogene strata in Southeastern Nigeria: Journal of African Earth Sciences, v.41, p. 79-102.

Pettijohn, F.J., 1975. Sedimentary Rocks: Harper and Row publishers, New York 628p.

Potter, P.E. and F.J. Pettijohn, 1963. Paleocurrents and basin analysis, New York Springer-Verlag, 87-89. 
Reijers, T.J.A., S.W. Petters, and C.S. Nwajide, 1997. The Niger Delta Basin. In Selley, R.C. (ed.), African Basin, Amsterdam, Elservier, p. 150-170.

Reyment, R.A., 1965. Aspects of the Geology of Nigeria: University of Ibadan press, Nigeria, 145p.

Reynolds, A. D., M.D. Simmons, M.B.J. Bowman, J. Henton, A.C. Brayshaw, A.A. Ali-Zade, I.S. Guliyev, S.F. Suleymanova, E.Z. Ataeva, D.N. Mamedova, and R.O. Koshkarly, 1998. Implications of Outcrop Geology for Reservoirs in the Neogene Productive Series: Apsheron Peninsula, Azerbaijan: AAPG Bulletin, v.82(1), p.25-49.

Schatzinger, R.A., and L. Tomutsa, 1999. Multiscale Heterogeneity characterization of Tidal channel, Tidal Delta, and Foreshore facies, Almond formation Outcrops, Rock Springs Uplift, Wyoming, In R. Schatzinger and J. Jordan, eds., Reservoir Characterization- Recent Advances: AAPG Memoir 71, v. $45-56$.

Shaikh, A.Z., A. Waleed, A. Haifa, H. Yahya, H. Hassan, C. Peter, and A. Shebab, 2004. Impact of Paleocurrent Analysis on Reservoir Description of Burgan Clastic Revervoirs, North Kuwait. Extended Abstract, AAPG Int'I Conf. (October 24-27, 2004), Cancun Mexico. 5p.

Sheldom, J.M., 2001. Influence of the west Virginia dome on paleocurrent patterns in the Upper Devonian-lower Mississipian Price Formation in the central Appalachians, Unpublished MSc thesis, Department of
Geology and Geography, west Virginia University, Morgantown, west Virginia. 334pp.

Short, K. C., and Stauble, A. J. 1967. Outline of geology of Niger Delta, AAPG Bulletin, Vol. 54, p. 750-780.

Simpson, A., 1954, The Nigerian Coalfield; The Geology of parts of Owerri and Benue Provinces: Bull. Geological Survey of Nigeria, no.24, 85p.

Smyth, D.G., 2004. Sedimentology and permeability characteristics of the Arroyo Ojito Formation (upper Santa Fe Group) Adjacent to the Sand Hill Fault, Albuquerque Basin, New Mexico. Unpublished Msc Thesis, Department of Earth and Environmental Sciences, New Mexico Institute of Mining \& Technology, Socorro, New Mexico. 171pp.

Steinmetz, R., 1962. Analysis of vectorial data, J. Sed. Pet., Vol. 32(4), p. 801-812.

Tao, W. and B.R. Roberts, 2003. Relationships of reservoir properties for shaly sandstones based on effective porosity. Petrophysics. Vol. 44 (5). Pp.328-341.

Tattam, C. M. 1944. A Review of Nigerian Stratigraphy. Report of Geological Society of Nigeria (1943).p 24-46.

Teoh, Y.J., 2007. Characteristics of sedimentary Facies and Reservoir Properties of some Tertiary sandstones in Sabah and Sarawak, East Malaysia. Unpublished MSc thesis, School of Physics, University of Sains, Malaysia. 119pp. 